\title{
Editors' Introduction: Forgetting Freud? For a New Historiography of Psychoanalysis
}

\section{Lydia Marinelli and Andreas Mayer}

Sigmund Freud Foundation Vienna and

Department of History and Philosophy of Science, University of Cambridge

How does the advancement of the sciences relate to the ways in which their founding figures are remembered? According to the stark picture painted by Alfred N. Whitehead in 1917, "the establishment of a reverential attitude towards any statement made by a classical author" had barred the progress of logic for several centuries: "Scholars became commentators on truths too fragile to bear translation. A science which hesitates to forget its founders is lost" (Whitehead 1917, 115). In the eyes of many critics (who often tend to equate science and logic in similar fashion), Sigmund Freud's psychoanalysis may well be an example of such a lost cause. From the founding book The Interpretation of Dreams ([1899] 1900) to his very last statements, Freud never ceased to affirm that psychoanalysis was a science: "What else can it be?" (Freud 1940, 282). Yet not only the fact that he has become one of the classic authors of the twentieth century, but also a number of very specific traits of psychoanalytic institutions (such as the numerous schisms resulting from personal fights between their members) have nourished the suspicion that Freud was less the founder of a science than of a sort of quasi-religious movement, a secular sect thriving on a personality cult.

Thus historians and philosophers of science have either avoided dealing seriously with psychoanalysis or have adopted a negative or even hostile position towards it. Revealing the "errors" committed by its founder, confronting the cherished "myths" about his discoveries with the brute "facts," and questioning his moral integrity and honesty have become a growing industry during the last thirty years. Much of the personal and polemical character of this historiography can be traced back to Freud's famous essay on the "History of the Psychoanalytic Movement" (Freud 1914). Rather than a sober historical exposition, this text was a furious polemic launched against detractors and dissidents and eventually led to the decisive split between the two major groups in Zurich and Vienna. Thus one of the basic tenets in writing the history of psychoanalysis was to enthrone its author as the only founding figure: "Psychoanalysis is my creation," writes Freud in his "History." "I consider myself justified in maintaining that even to-day no one can better know than I do what psycho-analysis is, how it differs from other ways of investigating the life of the mind, and what would better be described by some other name" (Freud 1914, 7). 
Since then, the majority of attempts to historicize psychoanalysis have been taken in by this Freudocentric account: regardless of whether they have sustained it or attacked it, they have accepted it as given. Up to the present day, psychoanalytic historiography has remained trapped in a Manichean logic, with the result being that an orthodox camp seeks to erect Freud as a monument while a heretical camp does its best to smash it by unveiling his moral and intellectual dishonesty and by pointing to other neglected figures (sometimes depicting them as martyrs or mounting them as counterheroes). Whereas "Remember Freud!" serves as the battle cry of the first camp, "Forget Freud!" is the answer of the second camp. This topical issue attempts to bring together contributions by various scholars that are intended to help us to leave behind the sterile polemics that still characterizes much of the present-day debate. Before we outline the contours of an alternative historiography of psychoanalysis, we will briefly review the major trends which dominated it during the last century. ${ }^{1}$

Following Freud's own example, early histories of psychoanalysis were strongly marked by the genre of biographical writing. Such a focus on a singular individual not only reflects the field's affinities with a wider non-academic readership, but is closely connected to a number of institutional and methodological specificities. More than in any other modern scientific project, autobiographical writing and methodological exposition are inextricably intertwined here. The Interpretation of Dreams was conceived by its author as a founding text, presenting not only a new theory of the unconscious and the psychical apparatus, but also a new method of interpretation. Because Freud never wrote his treatise on the psychoanalytic method, ${ }^{2}$ The Interpretation of Dreams acquired the status of the first technical how-to manual presenting "self-analysis" the confession of painful personal motives - as a didactic exercise. Although other nineteenth-century Victorian scientists (such as Charles Darwin) confided their insights in such confessional manner, the form of Freud's dream book is quite unique. This is due to the twist which, from the second edition (1909) onwards, declared the book to be a portion of the author's self-analysis, of "my reaction to my father's death, that is to say, to the most important event, the most poignant loss, of a man's life" (Freud [1899] 1900, xxvi). Thus, the self-analysis constituted not just a mere method which the author had illustrated by using his own dreams as an example: it became its veritable motive and source. By this reversal, the book appeared now as the necessarily incomplete testimony of Freud's own experience - an experience that he did not hesitate to attribute to all mankind. This intricate connection between the exposition of the technique of interpretation and the life history of the first interpreter had a lasting effect on the ways psychoanalysts referred to Freud as their "founding father" (see Forrester 1997a; Marinelli and Mayer [2002] 2003).

The biographical version of "remembering Freud, the man" is expressed in three projects written either during the last period of his life or shortly after his death.

\footnotetext{
${ }^{1}$ The following then does not attempt to be an exhaustive review of the historiography of psychoanalysis. This would be a subject in its own right.

${ }^{2}$ Freud worked on this treatise between 1908 and 1910, but later abandoned the project (see Freud 1910).
} 
The first of these attempts was published by Fritz Wittels under the title Sigmund Freud. Der Mann, die Lehre, die Schule in 1924. The author should be numbered among the early dissidents, for he had left the Vienna Psychoanalytic Society after a number of disputes with Freud, while continuing to practice as a psychoanalyst. The life of Freud is recounted here by adopting the autobiographical perspective of the former disciple, which oscillates between close contact with the master and critical distance. Wittels claims that "because of my distant position, I don't fall prey to the overwhelming proximity of a powerful personality. I am not a hypnotized yes-man, of whom Freud has already plenty, but a critical witness" (Wittels 1924, 7). To be sure, Wittels' biography praises Freud as the inventor of psychoanalysis, but it aims to demolish both its hypotheses and its techniques. In contrast to other "dissidents" such as Jung, Stekel, and Adler, he does not set an analysis of his own dreams against the Freudian model. Instead Wittels attacks the master's autobiographical, confessional writing itself, which similarly to the Catholic absolution seems to make him immune to any skeptical reading. Wittels opposes the strategy of linking the exposition of the principles of psychoanalytic interpretation to the author's personal deficiencies by citing biographical material from his own practice as a therapist, which is intended to corroborate a rival form of interpretation. ${ }^{3}$

Wittels' biography should be seen in a double context: firstly, as way of reinterpreting Freud's life in a way that supported a different therapeutic approach that also claimed the appellation "psychoanalysis" for itself, and secondly, as an early critique of the institutionalization of psychoanalysis, which is represented here as a crowd of hypnotized disciples (very much in line with the picture provided by Freud in his text on "group psychology"). ${ }^{4}$ Freud's reaction to the publication of this biography was expressed in a letter to Wittels which discouraged all future biographers: "Needless to say, I would never have desired or promoted such a book. It seems to me that the world has no claim on my person and that it will learn nothing from me so long as my case (for manifold reasons) cannot be made fully transparent" (Freud to Wittels, 18 December 1923, in Freud 1960, 350). Thus Freud's biography had already become a matter of institutional conflict during his own lifetime.

Two very different projects published after his death attempted to ground the life of the founding figure firmly in its orthodox institutions. Although both authors were among those disciples whom Wittels had classified as uncritical believers, their conceptions stood in marked contrast to each other. Each exemplified a distinct position with regard to the direction that the development of psychoanalytic institutions should

\footnotetext{
${ }^{3}$ When criticized by Jung for the incompleteness of his dream examples and the lack of sexual interpretations, Freud countered his critic with the paradoxical formulation that his book proved "the principles of dream interpretation by its own nature, so to speak, through its own deficiencies" (Freud to Jung, Feb 17, 1911, in Freud and Jung 1974, 395). For the epistemological and ethical implications of this strategy, see Marinelli and Mayer [2002] 2003, 101-111.

${ }^{4}$ It must be stressed that Wittels' later book Freud and His Time (1931) adopts a different strategy by constructing a framework taken from the history of ideas.
} 
take after Freud's death. Siegfried Bernfeld began publishing essays on Freud's life in the mid-forties, which in many cases were supplemented by further biographical studies prepared together with his wife Suzanne Cassirer during the fifties. These essays direct attention to the early phase, before the publication of The Interpretation of Dreams (Bernfeld 1944, 1949). They refrain for the most part from a psychoanalytic reinterpretation of Freud as a person based on the autobiographical details of his published works. Their method remains much closer to the empiricism of academic historiography.

Bernfeld meticulously collected material from Vienna archives with the help of a friend, steadfastly believing that someday it would be of use in the creation of a "definitive Freud biography." The impressive result was the first Freud archive, which conforms to the tenets of the positivistic tradition. ${ }^{5}$ It includes detailed information on the family's genealogy, an archive on important figures in Freud's life and work, and correspondence with contemporary witnesses. Bernfeld subjected the information he garnered from interviews and correspondence to a twofold examination before integrating it into his archive. ${ }^{6}$ He even systematized his methods of collecting material. In a number of texts, he dealt with the assemblage of material that could be independently confirmed and was suitable as "evidence" for obtaining historically grounded psychoanalytic knowledge. This methodology and the focus on the preanalytic works of Freud were of interest to Bernfeld because he himself had taken a physiologically oriented approach toward establishing the experimental measurability of psychoanalytic libido. Although his colleagues saw this project with great skepticism, he conducted a series of "libidometric" experiments that attempted to link psychical processes to a number of physically measurable energy quanta. By depicting Freud as a natural scientist, Bernfeld tried to outline a new prehistory for psychoanalysis, which could bring it a new legitimacy.

The Bernfelds' building blocks of a biography could not be assembled into a coherent whole, and thus a different project would win the status of the "definitive" Freud biography. The creation of a "definitive biography" was the declared aim of Ernest Jones, who began with this undertaking during the late forties. While the Bernfelds had primarily worked with official archives and contemporary witnesses, Jones was in close contact with the Freud family, who made available to him source material from the family archive. In the fifties, a number of memoirs on the master published by authors who were or had been Freud's close associates, including the psychoanalysts Hanns Sachs and Theodor Reik, had brought biographies into circulation, which had come under increasing criticism. In view of the growing memoir literature, the Freud family had become actively involved in shaping the founder's image. When Bernfeld announced his intention to publish his work on Freud's cocaine episode, he met with great resistance from the family, who sought to dissuade him (Trosman and Wolf 1973,

\footnotetext{
5 Today this archive is housed in the Library of Congress.

${ }^{6}$ See the letter from Bernfeld to Jones on 11 June 1951, cited in Grubrich-Simitis 1988, 29.
} 
232). Jones undertook his project with the stated goal of protecting the founder from "serious distortions and untruths," as he writes in his preface to volume one (Jones 1953-57, vol. 1, i). His biography derived its institutional function from his closeness to Freud and his family who had emigrated to England, and to his key position within the International Psychoanalytic Association. He intended to restore an image that met the expectations of a family concerned with discretion and an institution that invoked the "great man" as its founding father.

Jones integrated Bernfeld's work into his three-volume biography The Life and Work of Sigmund Freud, often modifying it only slightly and not always identifying it as such. Bernfeld's widow agreed to this, hoping as did many of the other analysts of this generation that the sooner an authorized biography were available, the less psychoanalysis would be exposed to attacks. In many ways, the silent incorporation of foreign elements into his book became programmatic for Jones' work. The biography was not only to deliver a new historiographic basis for the psychoanalytic collective: tacitly, the book itself was also a collective effort. In addition to utilizing material still in the family's possession, he also included a collection of memories concerning Freud. The memories were augmented and corrected by empirical material from the family, which Anna Freud made available piece by piece. In a next step, Jones submitted his material to her for "approval." Although the two were often of different opinions, this form of collaboration, whose modes of operation ranged from editing to censorship, was never altered during the writing of all three volumes (Steiner 2000). The result was a narrative that the official representatives of psychoanalysis could accept as the "true" Freud. One of the reasons why the agreement with Jones' book was so durable was the fact that he had been able to use sources and materials that for a long time remained under lock and key in the Freud Archives, some of which are still not accessible today. No later biography succeeded in even coming close to being able to compete with the status that the postwar generation of psychoanalysts accorded Jones' work.

The road to psychoanalysis remains, as it always has been, the reading of Freud's works. Despite all of the transformations that psychoanalysis has undergone, despite all of the authors who have expanded its canon, his texts have retained their intiatory status. This circumstance introduces a specific tension into its historiography. Firstly, it points out the fact that its conception of science continues to be determined by exegetic traditions, which derive their genuine dynamic from the interpretation of a text. Transformations can take place under the formula of a return to the founder, as can be seen in the case of Jacques Lacan. Secondly, and as a result, the texts themselves are accorded a status that is not merely historic, but also oriented toward current psychoanalysis. Early on, the significance of Freud's textual body of work for the training of therapeutic practitioners led to the implementation of institutional controls over Freud's work. This process was driven on by Freud himself after the First World War. With the founding of the International Psychoanalytic Press as his own avenue of publication, he was fulfilling several objectives. It was intended to ensure that aspiring analysts would be guaranteed the continual availability of his writings, which continue 
into the present to be treated as the textbooks of psychoanalysis. It was also intended to publish the works of those analysts who were accepted within the canon and to make possible the publication of a later complete edition of the writings under the aegis of his followers. At first glance, this great sensibility for Freud's body of work seems to represent a remarkable contrast to the current situation, in which both a complete edition and a historical-critical edition are lacking.

With regard to editorial considerations, the German-language Freud edition limped along behind the English Standard Edition by several decades. This can be explained historically: the Standard Edition's normalizing power was so strong that in the 1970s it was almost forgotten that the German text and editions were its basis. In 1980 a monumental six-volume concordance (Guttman, Jones, and Parrish 1980) to the Standard Edition appeared with the claim of having provided an index to a body of work on a scale that only occurs once in the publication history of an author. By registering almost every word of the English edition in its sentence context, this research tool sought to make the oeuvre transparent to research once and for all. Thus this concordance demonstrates the unshakable belief in the English Standard Edition's everlasting validity, or to be more precise, its superiority as the single legitimate translation. ${ }^{7}$ This new tool would allow researchers to make exact statements regarding how often "Freud used any term" (Guttman 1980, 487). What is remarkable here is not the undisguised euphoria stimulated by the early days of computer philology in the seventies, but the stress that was put on insisting that Freud's use of language had been analyzed.

The circumstances surrounding the translation's production contributed to this phenomenon: Freud authorized it himself and it was created in close cooperation with Anna Freud and Ernest Jones. Around 1980 which one could tentatively term the last zenith of American psychoanalysis, one forgot not only the provisional nature of translations, but also the provisional nature of the text that James Strachey presented not only as translator, but also as editor and commentator. During the twenties, the second generation of psychoanalysts had developed a certain sensibility for the historical genesis of Freud's work and the inadvisability of viewing it as a homogenous body of text. An indicator of this change is provided by an editing project undertaken in the course of the edition begun by the International Psychoanalytic Press in 1924 of the Gesammelte Schriften (Collected Writings). The matter at hand was a two-volume edition of The Interpretation of Dreams, in which one volume contained the original text from the year 1899 and the other cataloged the additions made in the later editions. The project was doomed to fail because it was based on the notion of the text's evolution through a progressive linear development. The transformations undergone by the text were much too complex to be subsumed under an additive process. Sections had also been rewritten or omitted in such a way that assumptions of the book's having undergone

\footnotetext{
${ }^{7}$ Only a few works of world literature have been subjected to a concordance. The concordance that the editors referred to was the Bible concordance of St. Anthony of Padua (1195-1231) (see Guttman, Jones, and Parrish 1980).
} 
a teleological development were destined to founder. The Gesammelte Werke, which was published initially by the Imago publishing company in London, represents the German standard edition to this day. In essence the collection is nothing more than a chronologically ordered reprint of the last available editions. The Interpretation of Dreams was put back into the form it had in its eighth edition, and the traces of history were for the most part swept away.

Due to the National Socialist expulsion of psychoanalysis from Germany and Austria, editorial efforts were redirected toward the English edition, which for several decades was much more normative in regulating psychoanalytic vocabulary and usage than the German original. The regulative effect was strengthened in that the Gesammelte Werke left out many works that would have granted access to the scientific prehistory of psychoanalysis. First and foremost, Freud's neurological writings were banished into a dark and irrelevant past. It was not until the 1960s, when psychoanalysis had reattained widespread social recognition in Germany and Austria, that the project of compiling a new edition was undertaken. The so-called Studienausgabe (Study Edition) comprises a selection of texts that are treated according to the model provided by the English Standard Edition; it adopts and translates the English commentaries and annotations. However, this collection also remains far from being a historical-critical edition: although it takes textual variations into account, it provides no information on the criteria according to which the changes have been noted. "Variations are only provided in instances where they seem significant enough to touch the sense of the passage at hand or can be recognized as a later change of opinion on the part of the author," is the lapidary explanation given in the editorial preface (Freud, Studienausgabe 1969-75, vol. 1, 31).

Freud's "last hand" hovered directly or indirectly over all editions of his works available on the market into the 1980s. And yet this close relationship to the author had been increasingly undermined from the other side. Since the sixties, extensive editions of his letters had appeared, putting his oeuvre into new contexts. These volumes of correspondence could not legitimate themselves by appealing to Freud's printed works, but instead introduced a new heterogeneous element. In these exchanges of letters one begins to appreciate the role played in the development of his works by correspondence partners, be it in providing ideas, criticizing, or censoring. Ideas which were soon discarded are often sketched out in these letters, as can be seen in the case of "Project for a Scientific Psychology." The publication of the complete correspondence with Wilhelm Fliess or the letters exchanged with Jung directed historiography in fully new directions and led to new readings of Freud's published work as well. Some editions of letters continue to be faced with the dilemma of having been compiled in an era in which the Freud family or the version of psychoanalysis prevalent at the time forced omissions, shortenings, and selections that are in some cases not identified as such. Many other materials remain in the Freud Archives of the Library of Congress under lock and key.

Given that psychoanalytic historiography has been heavily marked by a biographical and hagiographical style, the rare contributions made by historians of science have 
aimed first and foremost at putting Freud's endeavor back into its social and intellectual context. One of the key strategies of this contextualist historiography has been to draw on unpublished source material in order to reveal "the unknown history" of psychoanalysis. During the 1960s, the Swiss psychiatrist Henri Ellenberger published a number of articles retelling famous case histories in a symmetric form comparing biographical data about the patients with the published accounts (all republished in Ellenberger 1993). The general strategy of this revisionist historiography was to decenter Freud by bringing in a variety of other actors who usually were only represented by "the master's voice": after the patients, the importance of several colleagues and friends (Fliess, Breuer, Jung, etc.) was stressed, always with the strategy of revising the hagiographic picture painted by Freud himself and repeated by his disciples. In response to the heroic image of the discoverer of the unconscious, the role of the famous self-analysis was also reassessed. Ellenberger (1968) qualified the self-analysis as a "creative illness," likening it to the experiences of mystics and poets. Such a reading drew on the interpretive model of retrospective medicine, which treats historical (and sometimes fictional) persons as though they were real patients and, on this basis, claims the universal validity of present-day clinical diagnoses. A good portion of the revisionist historiography written by psychiatrists or doctors in this vein reopened the classic cases - Anna O., Emmy v. N., and even the "case of Freud" himself - with the attempt to give a new, a more "complete," or at least "objective" diagnosis (see e.g. Mahony 1996). As one would expect, much of this historiography sets out to correct the errors committed by Freud, questioning the soundness of psychoanalytic theories and their therapeutic value.

The lack of conceptual sophistication demonstrated by writing that came out of this tradition may well be explained by its basic tenet: to restore the historical "facts" and to undo the "myths" created by Freud and other psychoanalysts - certainly a noble endeavor, but also a project of infinite dimensions. Since the revisionist accounts are cast in opposition to the Freudocentric legends, they remain caught up in the mythical history they so passionately seek to combat. From an epistemological point of view, such work is stronger on the negative than on the positive side. It is easier to smash the old stories than to tell new, better ones. The revisionists may add more and more elements to the picture, but without being able to offer alternative models to account for and justify this complexity. Hence it comes as no surprise that the core section of a book like Ellenberger's (1970) is structured around the classic distinction of "life" and "work" and that it ends with a chronological list of events. In a more iconoclastic vein, this style has been adopted by Frank Sulloway ([1979] 1992), whose study is in many ways a typical representative of the odd relationship between psychoanalysis and the history of science. After restoring the context of Freud's theory of sexuality, with special attention to the role played by Fliess's biology, this author advances the thesis that psychoanalysis was fashioned as a sort of "cryptobiology." The book culminates in a catalog-like list that tracks down the myths in the Freud hagiography and contrasts them with the facts reconstructed by the historian. 
In marked contrast to the medical branch of retrospective diagnosis, Sulloway assembles all his material in order to demonstrate that psychoanalysis is not a proper science. His normative assessment fits in with that of a number of other critics who followed the line opened up by philosopher Karl Popper and continued (in a somewhat different vein) by Adolf Grünbaum. In one of the rare pieces published on the history of psychoanalysis in the most eminent history of science journals, Sulloway (1991) does more than confront the Freudian case histories with the patient's point of view: he also passes judgment on them for providing bad evidence for Freud's theories. Taking a strange turn, his argumentation relies heavily on work in the history and sociology of science (such as Latour and Woolgar [1979] 1986; Shapin and Schaffer 1986) that has drawn attention to the inextricably rhetorical nature of scientific proof. Sulloway's overall objective in pursuing this course is to denounce Freud's approach to persuasive textual strategies (Sulloway 1991, 274). It may seem ironic that these revisionist accounts of the basic values of scientific communities (public character of scientific knowledge, peer criticism, replication), as they were exposed in normative fashion by Robert Merton during the Second World War, are used here to reaffirm precisely such an idealistic picture of science.

During the last two decades, a whole literature industry has grown up around exploiting references to these older historical works as a means of debunking Freud's theories, and most importantly, his personal integrity as a scientist and therapist. The attacks leveled during the 1990s under the label of the "Freud Wars" led to the formation of the most surprising and unlikely alliances. Such is the case in the opening of the most recent bridgehead: the Livre Noir de la psychanalyse, which unites philosophers, psychiatrists, behavioral therapists, experimental psychologists, and historians. The celebrity of the target is a sufficient umbrella for extremely divergent claims, all of which share the hope that the sensationalist strategy of insinuating that the victims of psychoanalytic therapy can be seen on a par with those of the Gulag will serve their own particular cause. It may be consistent with their strategy of immunization against the all-pervasive influence of Freud's thought throughout the twentieth century that the historians and philosophers on board hold quite impoverished beliefs about society, human understanding, and psychological processes. Merely labeling psychoanalysis as a "sect" or a quasi-religious undertaking represents a paltry and banal attempt at explaining its successful dissemination in most of the Western countries. One may notice, however, that Wittels' depiction of Freud as a sort of master-hypnotist who managed to lull his patients and devout followers still strongly informs the social psychology of these critics. ${ }^{8}$ Not only does the recourse to such argumentation ignore the role of the intelligent skepticism that Freud himself assumes

\footnotetext{
${ }^{8}$ Hypnosis as a sort of explanatory model is clearly present in Frederick Crews' widely read attacks on Freud. It also informs the work of the philosopher Mikkel Borch-Jacobsen, who has specialized in writing against Lacan, Freud, and psychotherapy in general. He is one of the driving forces of the Livre Noir. For a clear exposition of the hypnotic model and its implications, see Forrester 1997b, 221-228.
} 
the patient or reader will take when approaching psychoanalysis, it also obstructs any critical engagement with his doctrines and practices. ${ }^{9}$

The contributions in this issue all propose histories for psychoanalysis that leave the Manichean scheme behind. They pay tribute to the specificity of its theoretical knowledge and its clinical practice, while remaining aware of the numerous transformations it underwent during the last decades. Since the history of psychoanalysis was mainly written outside the professional circles of historians, it is not surprising that academic scholars have kept a certain distance from the field. Most of the fruitful and critical exchanges between psychoanalysis and historiography date back to a time when readers of Freud were not pushed to take strong normative positions for or against his work (see e.g. Certeau [1975] 1988 and idem 1986; Davidson [1987] 2001; La Capra 1987).

The first set of articles offers accounts of the early development of psychoanalysis and dream analysis, which is usually dealt with by charting Freud's "precursors." Instead of following such a path, Jacqueline Carroy links Freud's Interpretation of Dreams to the cultures of self-observation of late nineteenth-century France and provides a new context for the famous "self-analysis." In the practice of Alfred Maury, whose book constituted one of the major references for the dream literature of the late nineteenth century, the dream appears as a source for autobiographical writing that connects lay people and scientists. In addition to Freud's self-analysis, his abandoning of hypnotic techniques is considered to be the other decisive step in the establishment of psychoanalysis. A number of authors were right in questioning the idea of a radical rupture, but they still tended to reduce the effects of psychoanalytic therapy to a sort of "suggestion." In contrast to such approaches, Andreas Mayer's contribution traces the emergence of the psychoanalytic setting by analyzing the material and social conditions under which earlier cultures of hypnotism operated. The article then seeks to provide an understanding of the peculiar arrangement of the Freudian setting in its final form, in which the entire object world of the consulting room is focused back onto the psychoanalyst as a "transference object."

The second set is devoted to Freud's Interpretation of Dreams, the book that John Forrester once aptly characterized as a "transferential machine" (Forrester 1997a, 183). Continuing his earlier work, this author reconstructs the influence of the dream book in the work of British intellectuals and scientists during the early twentieth century, arguing that the establishment of self-knowledge was in all cases marked by a process of forgetting Freud. Dealing with the same time period, Lydia Marinelli contrasts Freud's

\footnotetext{
${ }^{9}$ Social anthropologists and sociologists such as Rieff (1959; [1966] 1987; 1990) and Gellner ([1985] 2003) have provided richer and more thought-provoking critical accounts of the rise of the "therapeutic society" and of the successful career of the psychoanalytic belief system in the Western world. There is much need for a more systematic historical investigation of the relationships between the uses of faith in therapy and religious practices throughout the twentieth century.
} 
dream theory with the implicit forms of theorizing found in early cinema. Whereas the commonplace analogy between dream and film proves to be deceptive when seen through a psychoanalytic lens, linking the first silent movies to older psychological theories can account for the concrete conditions under which this analogy could take effect.

The next two articles aim to shed light on the nexus of trauma, film, and memory, engaging in different ways with what Ian Hacking has termed "memoro-politics" (Hacking 1995). Alison Winter traces the equation of memory and screening processes, showing how the use of films in military psychiatry countered the Freudian theory of the unconscious. Paradoxically this development was taken up by post-Freudian psychiatry in the United States. Ruth Leys' work also focuses on the visual. She investigates the degree to which the traumatic image reformulated the post-traumatic stress syndrome debate, to bring about a shift away from the classical Freudian paradigm that has dominated American psychiatry.

The studies by Elizabeth Lunbeck and Allan Young take conceptual aspects of psychoanalysis as their point of departure. Their work also traces lines of development in American psychiatry. Lunbeck investigates the debate within Anglo-Saxon postFreudian psychiatry regarding the appearance of new types of patients. She deliberates on the reasons why the borderline concept could become so successful. The text by Allan Young leads back to Freud yet again. He takes Freud's concept of evolution as the point of departure for an investigation of evolutionary psychiatry. Freud's Lamarckism, which was already outdated in his era, was dragged along in psychoanalysis as an anachronistic burden and in many cases dispensed with, while similar evolutionary theories were experiencing a revival in psychiatry.

By now it should be clear that in the present context of this issue "forgetting Freud" does not mean that his contributions have been overrated. The renewal of the historiography of psychoanalysis necessitates the abandonment of both the cherished myths circulated by its institutions and the repeated and repetitive assaults made by self-declared heretics and those who would liberate us from its influence on our selfunderstanding. "Forgetting Freud" denotes more a methodological stance, kind of a step back, a relaxed attitude combined with scholarly curiosity for questions that at first glance might seem to lie outside the realm of the historiography of psychoanalysis. To those who tend to believe that Freud is just a "fad" destined to fade away within the twenty-first century, one cannot but reply using Philip Rieff's assertion that if "Freud should fade, it will be only from the midst of faddists. This is entirely possible, for one way in which the fashionable remains so is by trying to stay a little ahead of the game; counterfashions are the ultimate weapons of the miseducated who like their ideas brand new and yet of a quality that does not change their minds. Whether in popular favor or disfavor, Freud remains important, for he thought profoundly about matters that must always concern not merely scholars and scientists, but also drunks and diners-out" (Rieff 1990, 65-66). 


\section{Acknowledgments}

The articles published here originate from a conference presented in December 2004 by the Sigmund Freud Foundation in Vienna. We would like to express our gratitude to this institution for the support it gave to the project from the very beginning.

\section{References}

Bernfeld, Siegfried. 1944. "Freud's Earliest Theories and the School of Helmholtz." Psychoanalytic Quarterly 3:341-362.

Bernfeld, Siegfried. 1949. "Freud's Scientific Beginnings." American Imago 6:163-196.

Certeau, Michel de. [1975] 1988. The Writing of History. Translated by Tom Conley. New York: Columbia University Press.

Certeau, Michel de. 1986. "Psychoanalysis and Its History." In Heterologies. Discourse on the Other, 3-16. Minneapolis, MN: University of Minnesota Press.

Davidson, Arnold [1987] 2001. "How to Do the History of Psychoanalysis: A Reading of Freud's Three Essays on the Theory of Sexuality." In The Emergence of Sexuality. Historical Epistemology and the Formation of Concepts. Cambridge, MA and London: Harvard University Press, 66-92.

Ellenberger, Henri F. 1968. "The concept of creative illness." Psychoanalytic Review 55(3):442-56.

Ellenberger, Henri F. 1970. The Discovery of the Unconscious: The History of Dynamic Psychiatry. New York: Basic Books.

Ellenberger, Henri F. 1993. Beyond the Unconscious: Essays in the History of Psychiatry. Introduced and edited by Mark S. Micale; translations from the French by Françoise Dubor and Mark S. Micale. Princeton, NJ: Princeton University Press.

Forrester, John 1997a. "Dream Readers." In Dispatches From the Freud Wars. Psychoanalysis and Its Passions, 138-183. Cambridge, MA and London: Harvard University Press.

Forrester, John 1997b. "Dispatches from the Freud Wars." In Dispatches from the Freud Wars: Psychoanalysis and Its Passions, 208-248. Cambridge, MA and London: Harvard University Press.

Freud, Sigmund. [1899] 1900. The Interpretation of Dreams. SE, vols. IV and V.

Freud, Sigmund 1910. "The Future Prospects of Psycho-Analytic Therapy." SE, vol. XI, 139-151.

Freud, Sigmund 1914. "On the History of the Psycho-Analytic Movement." SE, vol. XIV, 7-66.

Freud, Sigmund. 1924-34. Gesammelte Schriften, 12 vols., edited in collaboration with the author, Anna Freud et al. Vienna: Internationaler Psychoanalytischer Verlag.

Freud, Sigmund. 1925. "An Autobiographical Study." SE, vol. XX, 7-74.

Freud, Sigmund. 1940. "Some Elementary Lessons in Psycho-Analysis.” SE, vol. XXIII, 281-286.

Freud, Sigmund. 1940-1987. Gesammelte Werke, 18 vols. and one supplement, edited by Anna Freud et al. vol. 1-17: London: Imago Publishing since 1968: Frankfurt am Main: S. Fischer Verlag.

Freud, Sigmund. 1953-74. The Standard Edition of the Complete Psychological Works of Sigmund Freud, 24 vols., edited by James Strachey, et al. [referred to as SE]. London: Hogarth Press and the Institute of Psycho-Analysis.

Freud, Sigmund. 1960. Letters of Sigmund Freud, edited by Ernst L. Freud. New York: Basic Books.

Freud, Sigmund. 1969-75. Studienausgabe, 10 vols. edited by Alexander Mitscherlich, Angela Richards, and James Strachey. Frankfurt am Main: S. Fischer.

Freud, Sigmund and Jung, C. G. 1974. The Freud/Jung Letters. The Correspondence between Sigmund Freud and C.G. Jung, edited by William McGuire. Princeton: Princeton University Press.

Gellner, Ernest [1985] 2003. The Psychoanalytic Movement. The Cunning of Unreason. 3rd ed. Oxford: Blackwell. 
Grubrich-Simitis, Ilse. 1988. "Siegfried Bernfeld: Historiker der Psychoanalyse und Freud-Biograph." In Bausteine der Freud Biographie, edited by Siegfried Bernfeld and Suzanne Cassirer Bernfeld, 7-47. Frankfurt am Main: Suhrkamp.

Guttman, Samuel A. 1980. "Concordance to the Standard Edition of Freud's Writings: A New Research Tool." International Review of Psycho-Analysis 7:487-491.

Guttman, Samuel A., Randall L. Jones, and M. Stephen Parrish. 1980. The Concordance to the Standard Edition of the Complete Psychological Works of Sigmund Freud, 6 vols, Boston: G. K. Hall.

Hacking, Ian. 1995. Rewriting the Soul. Multiple Personality and the Sciences of Memory. Princeton, NY: Princeton University Press.

Jones, Ernest. 1953-57. Sigmund Freud. Life and Work, 3 vols. London: Hogarth Press.

La Capra, Dominick. 1987. "History and Psychoanalysis." Critical Inquiry 13:222-51.

Latour, Bruno and Steve Woolgar. [1979] 1986. Laboratory Life. The Construction of Scientific Facts. Beverly Hills, CA: Sage.

Mahony, Patrick J. 1996. Freud's Dora. A Psychoanalytic, Historical, and Textual Study. New Haven, London: Yale University Press.

Marinelli, Lydia and Andreas Mayer. [2002] 2003. Dreaming by the Book. Freud's "The Interpretation of Dreams" and the History of the Psychoanalytic Movement. Translated by Susan Fairfield. New York: Other Press.

Meyer, Catherine, ed. 2005. Le Livre Noir de la Psychanalyse. Paris: Éditions Les Arènes.

Rieff, Philip. 1959. Freud. The Mind of a Moralist. London: Victor Gollancz.

Rieff, Philip. [1966] 1987. The Triumph of the Therapeutic. Uses of Faith After Freud. Chicago and London: University of Chicago Press.

Rieff, Philip. 1990. The Feeling Intellect. Chicago and London: University of Chicago Press.

Shapin, Steven and Simon Schaffer. 1986. Leviathan and the Air Pump. Princeton, NJ: Princeton University Press.

Steiner, Riccardo. 2000. "Die Zukunft als Nostalgie: Biographien von Mythen und Helden...? Bemerkungen über Jones' Freud-Biographie (Teil 1 und 2)." Psyche 54:99-142, 242-282.

Sulloway, Frank J. [1979] 1992. Freud, Biologist of the Mind. Beyond the Psychoanalytic Legend. London: Burnett Books.

Sulloway, Frank J. 1991. "Reassessing Freud's Case Histories: The Social Construction of Psychoanalysis." Isis 82:245-275.

Trosman, Harry and Ernest S. Wolf. 1973. "The Bernfeld Collaboration in the Jones Biography of Freud." International Journal of Psycho-Analysis 54:227-233.

Whitehead, Alfred N. 1917. The Organisation of Thought. Educational and Scientific. London: Williams and Norgate.

Wittels, Fritz. 1924. Sigmund Freud. Der Mann, die Lehre, die Schule. Leipzig, Vienna, and Zürich: E. P. Tal.

Wittels, Fritz 1931. Freud and His Time. New York: Horace Liveright. 